\title{
Immunohistological findings in lip biopsy specimens from patients with Crohn's disease and healthy subjects
}

\author{
GRACIELA CRAMA-BOHBOUTH, F T BOSMAN, B J VERMEER, \\ A M VAN DER WAL, I BIEMOND, I T WETERMAN, AND A S PEÑA \\ From the Departments of Gastroenterology, Pathology, and Dermatology, University Medical Centre, \\ Leiden, The Netherlands
}

SUMmARY Biopsies of apparently normal buccal mucosa were taken from 14 patients with Crohn's disease and 13 healthy controls who were matched for dental status. Most patients had an increased number of lymphocytes around vessels in the subepithelial tissue and two showed fibrosis with moderate atrophy of minor glands. Plasma cells which contained immunoglobulin, predominantly $\operatorname{IgA}$, were only found around minor salivary glands in both patients and controls. Quantitative studies showed a significant increase in the number of cells containing $\operatorname{IgA}$ in patients compared with controls. No correlation was found between immunoglobulin pattern and disease activity, age, sex, or duration of Crohn's disease. A significant correlation was found between the activity of the disease, as defined by the Crohn's Disease Activity Index, and the number of plasma cells containing IgM.

Oral lesions in Crohn's disease which were first described in $1969^{1}$ have been reported by various groups since then. ${ }^{1-12}$ Basu et al ${ }^{1.3}$ found that $9 \%$ of patients with Crohn's disease had macroscopic abnormalities in the buccal mucosa while others have shown that buccal mucosa which is apparently normal on clinical inspection contains aggregations of lymphocytes in the connective tissue of minor salivary glands, compatible with chronic inflammation. ${ }^{1+18}$

In the present study we investigated the histology and certain immunological features of uninvolved oral mucosa of Crohn's disease patients during different phases of the disease, and compared the findings with those obtained in healthy controls.

\section{Methods}

\section{PATIENTS}

Fourteen patients with Crohn's disease, nine women and five men (Table) with a mean age of 34.5 years (range 21-71 years), were included in the study. In all cases the diagnosis had been confirmed histoiogically. The total duration of the disease ranged between four months and 29 years. Disease activity was recorded as a Crohn's Disease Activity Index with criteria used by the National Cooperative
Crohn's Disease Study. ${ }^{19}$ Treatment at the time of the lip biopsy was noted, with the site, and extent of disease, any extra-intestinal manifestations, and the dental status. None of the patients had a deficiency of folic acid, iron, or vitamin $B_{12}$.

\section{CONTROLS}

Thirteen healthy volunteers, eight women and five men with a mean age of 28 years (range $24-40$ years) and a dental status matching those of the patients, formed the control group.

ETHICAL ASPECTS

This study was approved by the Ethics Committee of our hospital, and all persons who took part were thoroughly informed about the purpose of the study and gave their consent.

\section{PROCEDURES}

Two biopsy specimens, each $4 \mathrm{~mm}$ in diameter, were taken under local anaesthesia with a biopsy punch from the inside part of the lower lip, one to the right of the midline of the lip, the other to the left of it. One of the biopsy specimens was snap-frozen and used for detection, by an indirect immunofluorescence method, ${ }^{20}$ of deposits of $\operatorname{IgA}, \operatorname{IgM}$, IgG, and complement along the basement membrane of the epithelium and around vessels and salivary glands. 
Table Clinical data of patients and healthy controls

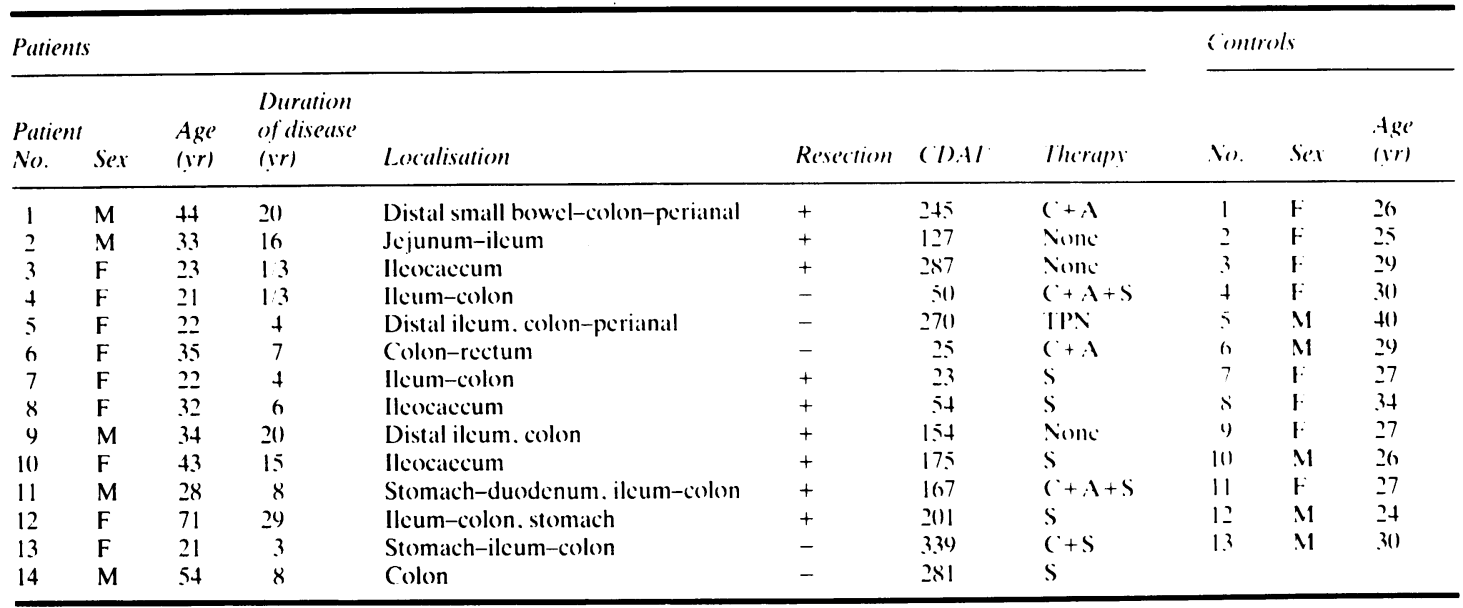

* Crohn's Discase Activity Index was determined according to Best et al ${ }^{10}$ at the time of the lip biopsy

$\mathrm{C}=$ corticosteroids. $\mathrm{S}=$ sulphasalazine. $\mathrm{A}=$ azathioprinc. $\mathrm{TPN}=$ total parenteral nutrition.

IMMUNOCHEMICAL STUDIES

Serial cryostat sections, 2-4 $\mu$ thick, were dried. incubated with fluorescein-conjugated antisera for 30 minutes at room temperature, washed in $0.01 \mathrm{M}$ phosphate-buffered saline $(\mathrm{pH} 7 \cdot 2)$, mounted in Tris-buffered glycerol $(0: 1 \mathrm{v} / \mathrm{v}, \mathrm{pH} 7 \cdot 8)$, and examined under a Leitz fluorescence microscope. Monospecific FITC-conjugated rabbit antisera against the heavy chain of human $\operatorname{IgM}, \operatorname{IgA}$, and IgG were obtained from NORDIC (Tilburg. Holland). Specific antisera against total complement was produced in rabbits and conjugated with FITC. The specificity of the antisera was confirmed by both immunoelectrophoresis and immunodiffusion and also by staining of bone marrow plasma cells producing monoclonal $\mathrm{IgG}, \operatorname{IgA}$, or IgM.

The other biopsy specimen was fixed in a sublimate-formaldehyde mixture ${ }^{21}$ for three hours and embedded in Paraplast ${ }^{\circledR}$. Tissue sections were cut ( $4 \mu$ thick) perpendicular to the mucosa surface and mounted on glass slides. Sections were stained with haematoxylin and eosin, and specifically for IgA, IgM, IgG by an indirect immunoperoxidase method described elsewhere. ${ }^{21}$ Plasma cells containing immunoglobulins, which were found only around minor salivary glands, were counted and the results expressed per $\mathrm{mm}^{2}$. Student's $t$ test was used for statistical analysis of the results.

\section{Results}

The biopsy specimens of almost all patients showed an increase of submucosal lymphocyte infiltrate. In two patients the biopsy showed fibrosis and atrophy of the minor salivary glands. and in one case there was an abnormal aggregation of lymphocytes in the connective tissue around minor glands. There was no correlation between the presence or degree of histological abnormality and the activity, site. extent or duration of disease: nor was there a relationship with the patients age and treatment (Table).

The immunofluorescence studies showed no clear deposits of $\operatorname{IgA}, \operatorname{IgG}, \operatorname{IgM}$, or complement in either patients or controls. With the immunoperoxidase technique we found Ig-containing plasma cells around salivary glands in both patients and controls. and $\operatorname{IgA}$ was the predominant immunoglobulin $(77 \%)$. The number of plasma cells containing $\lg \mathrm{A}$. IgG, and IgM around minor salivary glands was higher in Crohn's disease patients than in controls. IgA immunocytes per $\mathrm{mm}^{2}($ mean \pm SD) for

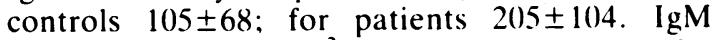
immunocytes per $\mathrm{mm}^{2}$ for controls $11 \pm 14$; for patients $24 \pm 24$. IgG immunocytes per $\mathrm{mm}^{2}$ for controls $16 \pm 15$; for patients $29 \pm 24$.

The difference was only statistically different for $\operatorname{Ig} A(p<0 \cdot 01)$. A significant correlation was found between the activity of the disease, as defined by the Crohn's Disease Activity Index, and the number of IgM-containing plasma cells $(\mathrm{r}=(\mathbf{0} \cdot 67, \mathrm{p}<() \cdot() 2)$ (see Figure).

\section{Discussion}

In agreement with previous reports, we found that the buccal mucosa from patients with Crohn's 


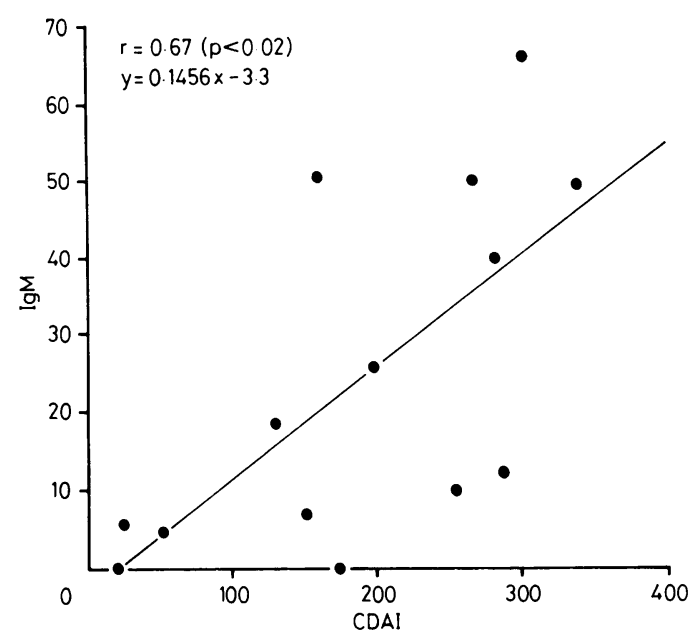

Figure Significant correlation between the activity of disease and the number of IgM immunocytes.

disease often showed histological abnormalities, which did not include epithelioid granulomas. The abnormalities are similar to those which occur in other parts of the gastrointestinal tract in Crohn's disease, and might be due to the same process. ${ }^{22}$ Fibrosis and atrophy of minor salivary glands were found in two patients; the lesions resemble those described in Sjögren's disease and have been reported previously in Crohn's disease. ${ }^{13}$

As far as we know, no other quantitative studies have been carried out on the immunocytes in lip biopsy specimens including minor salivary glands. Tissue culture and immunofluorescence studies on buccal mucosa $\mathrm{a}^{23}$ have shown that $\operatorname{IgA}$ is the most frequently synthesised immunoglobulin, followed by $\mathrm{IgG}$, and IgM. Using the immunoperoxidase technique, we found immunocytes to be similarly distributed around minor glands in patients and controls (IgA, 77\%; IgM, 9.5\%; IgG, 13.5\%).

The present study has shown that the number of $\operatorname{IgA}$-containing plasma cells is often increased in the uninvolved buccal mucosa of patients with Crohn's disease, but this was not correlated with disease activity.

We also found a significant correlation between the activity of the disease and the number of IgM-containing plasma cells. This finding suggests that during relapse an additional humoral defense system is activated, perhaps because of an already abnormal and greatly enhanced IgA response. Green and Fox, ${ }^{24}$ and Rosekrans et al ${ }^{25}$ have reported an increased number of IgM immunocytes in normal areas of the large bowel in Crohn's disease patients, but these authors did not investigate the correlation between their observations and the activity of the disease.

The present study documents yet another immunological abnormality in Crohn's disease. Further studies are needed to discover whether these abnormalities are the cause of, or are caused by, the underlying disease process.

We are indebted to Professor W van Vloten for instructing us in the lip-biopsy procedure, to $\mathrm{Mr}$ Wendel Hillebrands, Department of Dermatology. for technical help, to Mrs I Seeger for reading the English text, and to Gabrielle W M Verhoef for typing the manuscript.

\section{References}

1 Dudeney TP. Crohn's disease of the mouth. Proc Roy Soc Med 1969; 62: 1237.

2 Issa MA. Crohn's disease of the mouth. Br Dental J 1971; 130: 247-8.

3 Schiller KFR, Golding PL, Peebles RA, Whitehead R. Crohn's disease of the mouth and lips. Gut 1972; 12: 854-65.

4 Bishop RP, Brewster AS, Antonioli DA. Crohn's disease of the mouth. Gastroenterology 1972; 62: 302-6.

5 Croft CB, Wilkinson AR. Ulceration of the mouth, pharynx and larynx in CD of the intestine. Br J Surg 1972; 59: 249-52.

6 Stankler L, Ewen SW, Kerr NW. Crohn's disease of the mouth. Br J Dermatol 1972; 87: 501-4.

7 Ellis JP, Truelove SC. Crohn's disease with mouth involvement. Proc Roy Soc Med 1972; 65: 42.

8 Bottomley WK, Giorgini GL, Juliene ChH. Oral extension of the regional enteritis. Oral Surg 1972; 34: 417-20.

9 Eisenbud L, Katzka I, Platt N. Oral manifestations in CD. Oral Surg 1972; 34: 770-3.

10 Varley EW. CD of the mouth. Oral Surg 1974; 33: 570-8.

11 Fedotin MS, Grimmett GM, Shelburne J. Crohn's disease of the mouth. Dig Dis 1974; 19: 385-8.

12 Carr D. Granulomatous cheilitis in CD. Br Med J 1974; 4: 363 .

13 Basu MK, Asquith P, Thompson RA, Cooke WT. Oral manifestations of Crohn's disease. Gut 1975; 16: 249-54.

14 Basu MK. Oral manifestations of CD: studies in pathogenesis. Proc Roy Soc Med 1976; 69: 765-6.

15 Basu MK, Asquith P. Oral manifestations of inflammatory bowel disease. Clin Gastroenterol 1980; 9: $307-21$.

16 Walker JEG. Possible diagnostic test for Crohn's disease by the use of buccal mucosa. Lancet 1978; 2: 759-60. 
17 Matthews N. Tapper-Jones L. Mayberry F. Rhodes J. Buccal biopsies in diagnosis of Crohn's disease. Lancel 1979: 1: 50)(-1.

18 Basu MK. Chesner IM. Thompson RA. Asquith P. Significance of lip biopsies in the diagnosis of Crohn's disease. In: Peña AS, Weterman IT, Booth C'. Strober W, eds. Recent advances in Crohn's disease. Proceedings of the 2nd International Workshop on Crohn's Disease, Noordwijk, Leiden. The Haguc: Martinus Nijhoff. 1981: 43-6.

19 Best WR, Becktel JM, Singleton JW, Kern F Jr. Rederived values of eight coefficients of the CD activity index (CDAI). Gastroenterology 1979; 77: 843-6.

20) Herrman Werner, Kauffmann R, Es Lv, Daha M, Meijer Chr. A histological and immunofluoresence study of lesional and nonlesional skin. Arch Dermatol Res 1980; 260: 179-87.

21 Bosman F, Lindeman J, Kuiper G, van der Wal A,
Kreuning J. The influence of fixation on immunoperoxidase staining of plasma cells in paraffin sections of intestinal biopsy specimens. Histochemistry 1977; 53: $57-62$.

22 Cook MG, Dixon MF. An analysis of the reliability of detection and diagnostic value of various pathological features in Crohn's disease and ulcerative colitis. ( $j u t$ 1973: 14: 255-62.

23 Hurlimann J, Zuber C. In vitro protein synthesis by human salivary glands. I. Synthesis of salivary $\operatorname{IgA}$ and serum proteins. Immunology 1968; 14: 809-17.

24 Green FHY, Fox $H$. The distribution of mucosal antibodies in the bowel of patients with Crohn's disease. Gut 1975; 16: 12.5-31.

25 Rosekrans PCM. Meijer CJM, van der Wal AM, Cornclisse CJ, Lindeman J. Immunoglobulin containing cells in inflammatory bowel disease of the colon. Gut 1980); 21: 941-7. 